\title{
The Who? Didactics, differentiation and the biopolitics of inequality
}

\author{
Linus Bylund \& Beniamin Knutsson
}

The three didactic questions - what?, how? and why? - are increasingly supplemented with a fourth: who? Drawing on Therborn's distinction between difference and inequality, as well as on biopolitical theory, the present paper engages critically with the didactic who?-question. The paper situates the who?-question in broader discussions of educational differentiation, suggesting that it encompasses a tension between the recognition of difference and (re)production of inequality. Arguably, this tension becomes visible, and possibly more navigable, when we pose "Therbornian questions". The paper further suggests that the who?-question can be understood, in biopolitical terms, as a technique for constructing various student populations as appropriate for different kinds of education. Such management of difference, the paper warns, can easily slip into a biopolitics of inequality. Despite our critical observations, we conclude that there might still be radical potential in the who?-question, provided that it is handed over to the students and that careful attention is paid to societal relations.

Keywords: biopolitics, didactics, differentiation, education for sustainable development, inequality.

\section{Introduction}

The three core questions of didactics - what?, how?, and why? - are well known, at least to a Swedish audience. Ever since the 1980s, when didactics was institutionalized in Sweden as a scientific discipline closely linked to the teaching profession, these questions have been commonplace in discussions about the content and design of teaching. The didactic core questions have thus formed something of a hegemonic

Linus Bylund is PhD student in Subject Matter Education at the University of Gothenburg. E-mail: linus.bylund@gu.se

Beniamin Knutsson is Associate Professor in Subject Matter Education at the University of Gothenburg. E-mail: beniamin.knutsson@ped.gu.se 
triad, and they constitute a widespread technique that informs teachers' everyday conduct and their approaches to students. Anyone who has undergone teacher training during the past decades should be familiar with them.

In recent years, however, it has become increasingly common to see the three core questions accompanied by a fourth in discussions around didactics: who? (e.g. Didaktisk tidskrift 2018, Hartsmar \& Jönsson 2010, Ulrika 2017). The fact that, today, the who?-question not only appears, but is indeed emphasized, on the website of the Swedish National Agency for Education also signals something about its increasing significance:

The classic questions in didactics are what, how and why. [...] Over time, a number of other didactic question have been added, not least the all so important who-question. (Skolverket 2020, our translation)

The reasons for this development are probably manifold, and indeed warrant further research, but it seems plausible to suggest that increasing diversity and difference in the school sector have played a role. At the same time, it is important to recognize that considerations as to who the students are (and assumptions about their future lives) are not new, but have always been part of didactics (e.g. Klafki 1995, pp. 23-24, see also Rytzler \& Magnússon 2020). Naturally, such considerations are also not by any means isolated to the Swedish context. Rather, our point is that there appears to be a stronger articulation of the who?question today, and as increasing diversity in the school sector has become a global phenomenon (e.g. Banks 2015), our arguments should hopefully speak both to a Swedish and an international audience.

The aim of the present paper is to engage critically with the didactic who?-question. This is done in two ways: first, by discussing the who? question as being located in a field of tension between recognition of difference and (re)production of inequality and, second, by showing how it can be understood as a governing technique that involves knowledge or assumptions about the lives and future life trajectories of different student populations. In other words, the paper is concerned with the tension that the who?-question encompasses, and with its function as a mundane, and seemingly harmless, biopolitical technique. Both aspects, we argue, are important in order to understanding what is at stake whenever the who?-question is posed. Notably, attention is focused on cases where the who?-question refers to a collective of students rather than to individuals in a classroom. Hence, despite all the talk about individualization, we assume teaching to be an activity 
that is largely planned for, and implemented in relation to, collectives. This is what is being problematized in the paper, and in that respect our work is in stark contrast to, for example, Moira von Wright's (2000) discussion of the who?-question as a means to acknowledge the unique individuality of every student.

In our endeavour, we draw on sociologist Göran Therborn's $(2012,2013)$ analytical distinction between difference and inequality, on the one hand, and on Foucauldian literature on biopolitics, on the other (e.g. Foucault 1998, 2008, Lemke 2011), including works on the relationship between biopolitics and inequality (Wells 2011). The paper's approach is argumentative and theoretical, although we will use the example of a global education for sustainable development (ESD) programme to illustrate our argument.

The article contributes to previous research in three ways. Educational differentiation has indeed, and as will be shown in greater detail below, been subject to extensive scholarly discussions. However, the increasing use of the didactic who?-question, and how it relates to collective differentiation and inequality, remains unexplored and herein lies one contribution of the paper. Secondly, the article builds further on previous works concerned with biopolitical differentiation in ESD (Hellberg \& Knutsson 2018a, 2018b, Knutsson 2013, 2019, 2020). The paper contributes to this literature by adding to it a more didactic enunciation and by showcasing how the didactic who?-question can be understood in biopolitical terms. Thirdly, in contrast to von Wright's (2000) and others' subjectivity-oriented theorization of the who?-question as referred to above, the article offers a more society-oriented approach and it ends with some considerations as to the possibility of actually turning the who?-question into a tool for social critique.

The paper is organized as follows. The first section presents some arguments, found in previous educational research, for and against differentiation. Against this backdrop, the second section presents Therborn's analytical distinction between difference and inequality, while the third section introduces Foucauldian theory of biopolitics. In the fourth and main section of the paper, these theoretical perspectives are employed, alongside an example of a global ESD programme, to engage critically with the didactic who?-question. The concluding section summarizes our main arguments and considers whether there might be a radical potential in handing over the who?-question to the students. 


\section{Educational differentiation: Embracing difference or (re)producing inequality?}

Educational differentiation concerns, in various respects, the problem of managing diversity among students. This section presents some arguments, found in previous educational research, for and against differentiation. The literature on differentiation in education is vast, and the varying applications of the term pose challenges. Hence, the present overview is by no means comprehensive, but seeks to highlight some typical arguments from the literature. Notably, and as mentioned above, the paper is not concerned with individual differentiation, but focused on differentiation at the group level.

First, we turn to arguments that support differentiation. These arguments often take as their starting point a critique of homogenization and standards-based teaching and curricula. Instead of a one-size-fits-all education, proponents of differentiation argue that we must pay attention to differences in students' abilities, talents and life circumstances (e.g. Tomlinson 2000).

To address differences on the group level and adapt teaching to students' life circumstances and cultural identities, which clearly involves considering who the students are, some scholars have argued for pedagogical approaches that bring attention to students' "lived experiences". One such approach is place-based education (PBE), which embraces local diversity and seeks to challenge the homogenizing forces of economic globalization (Gruenewald \& Smith 2008). Drawing on John Dewey's critique of schools as places that fail to utilize children's everyday life experience, PBE aims to "ground learning in local phenomena and students' lived experience" (Smith 2002, p. 586). According to proponents of PBE, education grounded in the local community allows students to "realize the relevance of what they are learning and therefore become more engaged in the learning process" (Powers 2004, p. 18).

Other examples of pedagogical approaches that emphasize the lived experience of students are culturally responsive teaching (CRT) and multicultural teaching (MCT). CRT situates subject matter content within the lived experiences and frames of reference of students and is defined by Geneva Gay as "using the cultural characteristics, experiences, and perspectives of ethnically diverse students as conduits for teaching them more effectively" (Gay 2002, p. 106). According to CRT proponents, using the approach makes subject matter content more meaningful and allows it to be learned more easily and thoroughly, as teaching is adapted to students' world: their experiences, values and references (Gay 2002, Wlodkowski \& Ginsberg 1995). Similarly, 
Christine Sleeter and Judith F. Carmona (2017) argue that MCT enables alternative pedagogies that reflect students' lived experiences, thus avoiding teaching strategies that violate their home cultures and languages. Such culturally adaptive or relevant pedagogy - sensitive to cultural differences among students - is seen as emancipating for minority groups and is argued to have the potential to promote collective empowerment and to break the hegemony of cultures associated with "the white, middleclass mainstream” (Ladson-Billings 1995, p. 159). Hence, the more critically oriented arguments for educational differentiation target hierarchies and unequal conditions within education, challenging the status quo of the social order.

We now turn to arguments against differentiation. Scholars who argue against educational differentiation are often concerned with inequalities related to the reproduction of class, ethnicity and gender patterns. For example, Jeannie Oakes (1986) stresses that students from poor and minority backgrounds are disproportionally placed in low-ability groups or tracks designed for non-college-bound students. These students are also underrepresented in various programmes for the gifted. Further, she argues that these students are given fewer opportunities in class to formulate their own questions and reflect on different solutions. This is also found by Mattias Nylund, Per-Åke Rosvall and Kristina Ledman (2017), who claim that Swedish upper secondary school vocational programmes lack education in critical and scientific ways of thinking and that knowledge within these programmes is strongly context-bound and often related to regulating behaviours. Drawing on the theories of Bernstein and Bourdieu, Nylund et al. conclude that "working-class youth have one curriculum whilst those of a more middle-class background have another" (p. 805) and point to the problem that this differentiation prepares different students for very different roles in society.

Other scholars, such as George Ansalone (2010), have argued that differentiation does not merely create different learning trajectories for different students, but also different learning environments, functioning as a "socializing structure" within which students evaluate themselves and through which teachers gain information about students. This affects the curriculum, as different students are offered different competencies, thereby enhancing "the social construction of underachievement" (Ansalone 2010, p. 14). To address such constructions, Jan Terwel (2005) argues that instead of conceiving of students as individuals to be fitted into static pre-determined categories, they should be seen as "participants in a dynamic culture" involved in "fluid processes of identity formation and life-style development" (pp. 667-668). 
It would seem, then, that there are valid arguments both for and against educational differentiation at the group level, which, in turn, prompts questions as to when differentiation can be seen as a way of handling difference and when it instead runs the risk of (re)producing inequality. This tension between difference and inequality brings us to the next section.

\section{Distinguishing between difference and inequality}

To shed some new light on the debate on educational differentiation, and on the didactic who?-question, we can turn to works by the renowned sociologist Göran Therborn (2012, 2013). This section presents Therborn's multidimensional understanding of inequality, starting with how he distinguishes between difference and inequality.

In the late 1960s, Therborn contends, several critical intellectual strands became increasingly concerned with the issue of "difference" and with the right to be respected as different. Such perspectives have, for example, influenced certain proponents of educational differentiation, as referred to above (e.g. Sleeter \& Carmona 2017, Gay 2002). Somewhat inspired by these discussions, Therborn (2012, 2013) seeks to tease out how to distinguish between difference and inequality. He suggests three main ways. First, an inequality is always vertical or hierarchal in orientation, with someone or something being higher or lower, better or worse, while a difference may be horizontally oriented. Second, while a difference can be a matter of taste or categorization, an inequality always involves a violation of a moral norm of equality among human beings. According to Therborn, this does not presuppose a norm of complete equality, but only that the difference is too great and/or has an undeserved direction; in other words, the wrong people are given the best rewards. The third and last distinction between difference and inequality is that an inequality also has to be abolishable. As Therborn argues, the greater physical stamina of young compared to old people is not an inequality, while the difference in health status across different groups in society is (Therborn 2012, p. 579). Hence, differences are given or chosen, while inequalities are always socially produced. As will be shown below, this argument is highly relevant to the didactic who?-question and to matters of educational differentiation more broadly.

What, then, is an inequality? Therborn rests on a capability approach to (in)equality. That is, equal capability to function fully as a human being is used as the theoretical basis for analysis, and as a consequence, inequalities are seen as violations of basic human 
rights (Therborn 2013, p. 41). The capability approach does not include a list of central capabilities, but is rather focused on basic dimensions of human life, which include humans as organisms with bodies susceptible to pain, sickness and death, humans as persons living their lives in meaningful social contexts, and humans as actors capable of acting towards goals. From these dimensions, Therborn derives three different kinds of inequality, which constitute the basis of his multidimensional theory of inequality. These are vital inequality, which refers to socially constructed unequal life-chances of health and longevity, existential inequality, which concerns unequal allocation of freedom, autonomy and rights to self-development, and resource inequality, which refers to when humans are provided unequally distributed resources, often measured in income and wealth (Therborn 2013, p. 49). For Therborn, these socially produced inequalities of health, dignity, wealth and education are "killing fields", because they result in millions of premature deaths every year (Therborn 2013, pp. 54-67).

As will be shown below, Therborn's analytical distinction between difference and inequality can help us to navigate the tension that the didactic who?-question encompasses. But before that, biopolitical theory will be introduced.

\section{Biopolitics and inequality}

Biopolitics, for Foucauldians, refers to the government of life at the collective level, and theory of biopolitics enables inquiries into how populations or minor collectives are governed, categorized and separated (Dean 1999, Foucault 1998). Today it is widely accepted that the Foucauldian theory of biopolitics is useful when studying education (e.g. Ball 2012, Peters \& Besley 2007) and, as argued here, it can also be helpful when considering the didactic who?-question and its relationship to inequality. This section starts with a short remark on Foucault's general view of government before proceeding to the specific concept of biopolitics and how it relates to liberalism, to the liberal problem of inequality and, ultimately, to what we refer to as the biopolitics of inequality.

In Foucault's analyses of power, the concept of government is central - conceived by him as the conduct of conduct (Foucault 1982). Government thus refers to a more or less calculated and rational art of acting on the actions of individuals or collectives, so as to inform, guide or modify how they conduct themselves. Government is exercised by a multiplicity of authorities and actors in society, and 
it operates on different levels, ranging from the biopolitics of the population down to the inner techniques of governing the self. The term "techniques", for Foucauldians, refers to concrete and mundane "tools for the conducting of conduct" (Miller \& Rose 2008, p. 16). This includes organizational and practical devices for calculation, categorization, and governing, and as such, we argue, the didactic who?-question should qualify (as should, for that matter, the three didactic core questions). Foucault further suggested that government could be seen as a contact point where techniques for governing others and governing oneself typically interact (Burchell 1993, Hansson, Hellberg \& Stern 2015). This suggestion, as we shall see, has some resonance if we conceptualize the didactic who?-question as a governing technique.

According to Foucault, biopolitics emerged in the passage to modernity (Foucault 1998, 2008). Previously, sovereign power had been the dominant form of rule. Sovereign power was repressive and exercised as a means of deduction "of things, time, bodies and ultimately of life itself" (Foucault 1998, p. 136). However, as modernity evolved, states became increasingly concerned with investing life, i.e. fostering capabilities, skills and behaviour so as to optimize their populations and secure them from ills. This "biopolitics" required production of knowledge about the living conditions and lifestyles of populations, i.e. a conception of who they are collectively and how they lead their lives, in order to be able to design "appropriate" interventions (Foucault 1998, Lemke 2011).

Two things are important here. First, that the population, in Foucauldian terms, does not mean the totality of individuals within a legal or political entity but rather a "social body" (Lemke 2011, p. 36) characterized by its own internal processes, e.g. longevity, income, health status. It is "the collective embodiment of the targets of power", be it in the form of "an entire population, or a specific group of prisoners, school children, the insane and so forth" (Hewitt 1983, p. 71 , our emphasis). Biopolitics is thus concerned with the government of collectives that are grouped together by certain characteristics and the ways in which their conduct can be shaped (Lemke 2011). Second, that the "population" is an epistemic construction (Foucault 1998, p. 25). Hence, the act of grouping individuals together in accordance with certain characteristics entails an element of construction (Hacking 1986, Ball 2012). As will be shown, this "constructive" element is also critical to our conception of the who?-question as a governing technique.

Foucault (2008) further links biopolitics to the emergence of liberalism. In Foucauldian thought, liberalism does not refer to a political ideology or economic theory, but to a practical art of government 
that uses the capacities of free individuals and collectives as a means to achieving its goals. Liberalism assumes agency, i.e. that those who are governed are capable of thinking, acting and exercising a certain degree of freedom (Dean 1999, Hansson, Hellberg \& Stern 2015). Liberal government thus seeks to encourage, entice and empower subjects to exercise their freedom in the "right" way. The liberal problem, therefore, is how to govern without governing "too much" (Foucault 2008, p. 319) because liberalism, unlike sovereign power, has to respect the liberties and rights of the governed. This brings us to the issue of inequality.

Although the concept of inequality is rarely foregrounded in the literature on biopolitics, it is obvious that the divisions and hierarchical categorizations of life related to class, race, sex, ability and species, that biopolitical research has exposed (e.g. Lemke 2011) - not to mention processes of exclusion and subjugation whereby some forms of life are rendered surplus or even entirely disposable (e.g. Agamben 1998, Duffield 2007) - are intimately connected to inequality.

Yet there are biopolitical works that engage more specifically with the concept of inequality. Some scholars have suggested that the biopolitical production of populations, divided into categories according to their function and utility, is entwined with a political economy of inequality indispensable to capital accumulation (Giroux 2008, Venn 2009). A more interesting angle to us, however, is Karen Wells' (2011) argument that inequality poses a legitimacy problem to liberal biopolitics:

This is so because once the management of the health and welfare of the population becomes the justification for government it has to account for why increases in health and welfare are so unequally distributed. Inequality cannot be justified on its own terms - as it could under sovereignty - but instead has to be naturalised and individualised. (Wells 2011, p. 17)

As suggested by Wells, inequality does not constitute a predicament to sovereign power but to liberal biopolitics it does. In liberal biopolitical regimes, this problem is handled by constructing inequality as something normal to which government interventions must adapt. Hence inequality has to be thought of as a "natural" condition in which government operates, rather than as a product of government. To us, this is what a biopolitics of inequality is all about: a governing of life that presupposes, adapts to, normalizes and reproduces inequality. As argued elsewhere, such normalization of inequality is a salient feature of global ESD implementation (Knutsson 2019, 2020) and it 
also strikes us as an important element of a broader problematization of the didactic who?-question.

\section{The didactic who?-question: Between the management of difference and the biopolitics of inequality}

Drawing on the two theoretical perspectives presented above, this section engages critically with the didactic who?-question. First, we elaborate on how the who?-question can be understood as a mundane governing technique with biopolitical dimensions. Thereafter, we discuss the who?-question as located in a field of tension between the recognition of difference and (re)production of inequality. ${ }^{1}$ Our theoretical arguments will further be illustrated with an example from the world's largest ESD programme, called Eco-Schools. The programme, currently operating in 68 countries worldwide, aims to engage young people in protection of their local environment by using a participatory approach involving students, teachers and the surrounding community (Eco-Schools 2020).

The Eco-Schools example has been chosen as it serves to illustrate our theoretical arguments about the stakes that the didactical who?-question involves. Hence, just to be clear, our aim is not to make an empirical contribution to the existing and quite extensive literature on Eco-Schools. Rather the example is used to illuminate our didactical theoretical points.

\section{Understanding the who?-question biopolitically}

In all its mundanity, the didactic who?-question can be understood as a governing technique, i.e., a tool for the conduct of conduct. This tool helps to guide the everyday work and self-conduct of the teacher regarding, for example, how (s)he searches for, and selects and organizes, content and material deemed relevant to different collectives of students. However, as the didactic who?-question also informs the way in which these collectives of students are approached, it arguably constitutes a contact point between the teacher's self-government and the government of her/his students. It is at this latter point that the biopolitical dimension comes in.

Whenever the who?-question is posed, by an individual teacher or a team of teachers, in relation to a collective of students, at least two efforts are at play. First, there is an attempt to, at an abstract 
and aggregated level, characterize these students' knowledge, lived experiences and living conditions and, second, an attempt to determine how teaching can be adapted and made relevant to this particular collective of students. Such efforts to categorize students, and group them together, based on some (conceived) characteristics - in order to find "suitable" teaching methods and materials adapted to these characteristics - inevitably involves an element of construction. In other words, based on more or less solid knowledge about who the students are, i.e. how they lead their lives and what their future life trajectories will be, they are categorized in a particular way and constructed as being in need of particular educational interventions. Such categorizations also make it possible to distinguish between different student populations. Hence, the who?-question has some biopolitical features. First, it not only functions to conduct teacher conduct in the planning and organization of teaching, but also seeks to conduct the conduct of students, as they are the target of the adapted education. Second, it can be conceived of as a technique that constructs, and enables differentiation between, student populations in order to optimize their education in accordance with some known or assumed characteristics related to their lives.

The Eco-Schools programme can be used as an example to illustrate our theoretical point that ideas about who the students are have far-reaching implications for how they are approached. Schools enrolled in the Eco-Schools programme independently select the projects they undertake and how they go about implementing them, and in this way it reflects a liberal biopolitics (cf. Knutsson 2020). According to the Eco-Schools' global website, the programme is to be rooted in the local community and engage students in "problems at a level where they can see tangible results" with an overall ambition to have a "life-long positive impact on the lives of young people" and to change "behavioural patterns" that the students will "carry with them through life". Hence, the programme aims at fostering capabilities and optimizing the lives of the students. In doing so, it aims to produce environmental conduct among students, and the programme emphasizes that the greatest achievement is "the fact that it produces generation after generation of sustainably minded, environmentally conscious people" (Eco-Schools 2020).

Being a global programme, it has to address the diversity among enrolled students. This is done locally, as teachers at each school are free to decide which projects they see as relevant and what conduct to promote. A quick comparison between best practices of Eco-Schools in two countries indicates that the choice of what conduct should be instilled in the students depends on who the programme is targeting. 
In Sweden, the "sustainable school of the year" laureates of 2018 and 2019 were awarded for a variety of efforts, such as improvement of the schools' recycling facilities, information campaigns on sustainable consumption, cooperation with other schools as well as the dissemination of information on sustainable lifestyles through social media and at international student conferences (Grön flagg 2019). In Uganda, best practices are portrayed in a rather different way. Here, the students are targeted to become "innovators and inventors of cheap and easy technology that reflects their local environment" (Martin 2017, p. 7), technologies such as washing facilities built of re-cycled plastic cans or construction of water harvest tanks. Other highlighted projects are farming of bananas and design of medicinal herbal gardens, skills the students can later apply in their own communities at home (Martin 2017).

As demonstrated elsewhere (Knutsson 2020), and as is evident in the example above, differentiation is built into the Eco-Schools programme, as it takes the needs of the local communities and students' lives as its starting point. When teachers adapt subject matter content and address problems relevant to students' (future) lives and their local level, it is inevitable that the question of who the students are and what kind of life they are presumed to live in the future will be posed. Whether explicitly or implicitly, the didactical who?-question can therefore be seen as one of the mundane techniques that make it possible to handle and govern the great diversity among the students participating in the programme. Hence, even though the overall mission of the Eco-Schools programme is to produce a sustainably minded generation of people, the example above suggests that this mission is implemented in very different ways in relation to different categories of students. The example thus illustrates that the who?-question, and the differentiation that it is inexorably associated with, can be understood biopolitically.

\section{Between the management of difference and the (re)production of inequality}

As shown above, educational differentiation can be seen as a pedagogical way of handling diversity among students, but it can also raise concerns about inequality. When taking into consideration who the students are, and when allowing educational content to be adapted to students' lives, lifestyles and interests, some argue that students' educational performances can be improved. However, sensitivity to who the students are can also be connected to inequality, as educational 
adaptations easily feed into and (re)produce social patterns related to students' living conditions and social background. Hence, in our view, the didactic who?-question is situated within a field of tension between management of difference and (re)production of inequality.

In trying to navigate this field of tension, we argue that Therborn's distinction between difference and inequality can be useful, as it enables us to pose a number of relevant questions. According to Therborn $(2012,2013)$, as was shown above, an inequality has to be hierarchal in orientation, violate a moral norm of equality among human beings, and be abolishable. Taking these criteria as a starting point, we suggest that a number of "Therbornian questions" can be posed to consider whether educational adaptation to students' (presumed) life circumstances and lived experiences leans towards a difference or an inequality. Hence, whenever individual teachers, teams of teachers or school management representatives categorize students in a certain way, and consider how teaching should be suitably adapted to them - thereby explicitly or implicitly raising the didactic who?-question - the following questions might be reflected on: Does educational adaptation to various students' (presumed) life circumstances and lived experiences reflect a difference or an inequality? Is it simply a horizontal difference in terms of preferences or can we imagine a hierarchy with regard to the education that different students are exposed to? Are we taking the students' life circumstances as something given or as something produced and thus changeable? Hence, do we, in our teaching, handle inequality under the premise that it is abolishable? Finally, are the differences in how student collectives are approached so great that they, at the end of the day, violate a moral norm of equality among human beings?

To illustrate our theoretical point, we can once more turn to EcoSchools. In the example above, the answer to the who?-question seems to be that the Ugandan students are (constructed as) coming from a poor background and therefore in need of skills to secure basic health, nutrition and sanitation, while the Swedish students are (constructed as) being in need of skills to live a "greener" life within the parameters of a mass consumption lifestyle. Even if most students in Sweden and Uganda are living very different lives, this example raises questions. Do the differentiated ways in which the Eco-School programme is unpacked constitute a legitimate method of handling difference, or does it feed into, and (re)produce, a global pattern of inequality? Some might argue that it is reasonable to use education to address acute problems related to basic needs and that marked differences in lifestyle demand differentiation. However, another reasonable standpoint could be that education has a particular objective to challenge socially produced inequalities and that the differentiated 
practice in Sweden and Uganda fails to do so. These two standpoints can be viewed as different positions within the field of tension that the who?-question encompasses, a field that arguably becomes more navigable by posing "Therbornian questions".

When applying "Therbornian questions" to the Eco-Schools example above, it could be argued that the educational differentiation within the programme leans towards an inequality rather than a difference. It could be seen as an instantiation of a hierarchy of capabilities and lifestyles that divides rich and poor. The programme could further be seen as feeding into and sustaining this hierarchy by educating one group of students to live a greener life as mass consumers and offering them skills in ICT and dissemination of information, whilst educating the other in subsistence farming with skills in invention of cheap and easy technology made out of trash. It is very difficult to ignore the fact that the abysmal vital, existential and resource inequality that separates these populations breaks a moral norm of equality. If education reproduces this divide, it seems reasonable to suggest that it violates a moral norm of equality among human beings.

In this example, when the who?-question is explicitly or implicitly raised, it seems as if Ugandan and Swedish students are constructed as having radically different life trajectories with commensurate differences in skills and knowledge needs. Furthermore, it seems to do little, if anything, to challenge such unequal life opportunities. Rather, following Wells' (2011) arguments, inequalities appear to be conceived of as a "natural" condition to which the education simply adapts. Hence, in the example, inequality does not seem to be treated as something that is abolishable. However, it could be argued that education should not be a part of the naturalization of inequalities, but that its ethos should be to question and destabilize such categories. In this case, it would make a difference if the inequalities were to be analysed according to the questions above and be conceived of as produced rather than natural.

Finally, someone might argue that the example of the differences between Uganda and Sweden is an extreme one (although the implication of that very argument is that we are living in a world of extreme inequality). This example was chosen based on its salience. However, in our argument, the "Therbornian questions" might just as well, and should indeed, be raised in relation to intra-national differentiation between, for example, student populations in affluent and marginalized areas, or by individual teachers working with students from both vocational and academic tracks. In other words, they should be raised whenever and wherever the didactic who?-question is posed. 


\section{Conclusions}

The present paper has engaged critically with the didactic who?-question and situated it in broader scholarly discussions about educational differentiation. In this concluding section, we summarize our findings and then briefly consider the radical potential of handing over the who?-question to the students.

Our findings suggest that the who?-question encompasses a tension between the recognition of difference and (re)production of inequality. Therborn's $(2012,2013)$ work can be used to make this field of tension visible, and possibly more navigable. Naturally, it is impossible to exactly determine one's position between the two poles. However, by asking "Therbornian questions", it is possible to get an indication as to whether differentiation starts to become problematic. Does educational adaptation to different student populations reflect a horizontal difference or a vertical inequality? Are differences in students' living conditions treated as given or as socially produced and thus abolishable? Are the differences in how students are approached so great that they, at the end of the day, violate a moral norm of equality among human beings? Whenever and wherever the didactic who?question is posed, we suggest that these matters ought to be taken into consideration.

Our findings further suggest that the didactic who?-question can be understood biopolitically, i.e. as a tool for constructing various student populations as appropriate for different kinds of education. Based on more or less solid knowledge or assumptions about the students' lives and future life trajectories, they are categorized and made "suitable" for particular educational interventions. The who?-question can furthermore be seen as a contact point between the biopolitical governing of student collectives and the teacher's governing of her/himself. In all its mundanity, this governing technique might seem harmless, but we argue that it should be used with caution. Educational management of difference can easily slip into a biopolitics of inequality, that is, a governing of human life that adapts to, normalizes and (re)produces inequality. As shown in previous research, the global implementation of ESD is one area in which this problem appears to be particularly salient (Hellberg \& Knutsson 2018a, 2018b, Knutsson 2019, 2020).

Despite our critical observations, we would like to end by briefly considering the radical potential of handing over the who?-question to the students themselves. Again, our concern is not with how the who?-question can be used to recognize every student's unique individuality (cf. von Wright 2000), but rather with how it can be twisted 
into a means of social critique. On that note, we can turn to Klafki (1998) and to Niclas Månsson and Jonas Nordmark's (2015) discussion of his work, before finally returning to Foucault.

Solidarity occupies a central position in Klafki's thinking and his critical-constructive didactics encompasses three principles that should inform didactic questions: self-determination, co-determination and solidarity (Klafki 1998, pp. 311-312). In Månsson and Nordmark's (2015, p. 15) interpretation of Klafki, this implies that students should be given the opportunity to explore their own, as well as others', place in society and whether or not relations between people are characterized by solidarity or not. The implication of this argument for the present paper is the following. Rather than determining from the beginning who the students are, teachers could allow students to explore this themselves, as well as what the characteristic features of the relations between themselves and others are - that is, to "turn people towards, rather than away from, each other" (Månsson \& Nordmark 2015, p. 10, our translation). Note that this should not be understood as a simple resort to self-categorizations, but rather as a way to bring the relations between different socially constructed groups of people in society into focus. In other words, this entails taking a society-oriented, rather than subjectivity-oriented, approach.

Again, the example of the global implementation of ESD can be used to illustrate the argument. Previous biopolitical research has suggested that in progressive attempts to localize ESD, and make it relevant to the lived experience of particular groups, it is adjusted to comply with different socio-economic living conditions. This adjustment of ESD to who the students (presumably) are, and to the contexts in which they are situated, typically involves a depoliticized notion of local "realities" as something given and isolated rather than produced and relational (Knutsson 2019, 2020). The implication of this is that inequality becomes effectively normalized. Handing over the who?-question to the students themselves, and allowing them to explore the nature of relationships between their own communities and other communities and institutions, might very well be one of the most subversive ways of addressing this problem in the context of ESD - as well as beyond. Such a move would also be reminiscent of Foucault's notion of "tactical reversal" (Foucault 1998, p. 157). What Foucault meant was basically that the deployment of a technology of government - in our case, the who?-question as concomitant to a biopolitics of inequality - could be turned against the deployment itself - in our case, be twisted into a means of critiquing social inequality. Hence, as a didactic technique, the who?-question could potentially twist out of the grip of the logics under which it typically operates. 


\section{Acknowledgements}

This work is part of the research project Education for sustainable development in an unequal world: Populations, skills and lifestyles, funded by the Swedish Research Council (Vetenskapsrådet 201804029). We wish to thank our project colleagues Sofie Hellberg and Jonas Lindberg, the Critical Education Research group (KRUF) at our department, and the two anonymous referees for their helpful comments on earlier drafts.

Note

1. This field of tension also has some resemblance to the discussion on different conceptions of equity (e.g. Englund \& Quennerstedt 2008).

\section{References}

Agamben, Giorgio (1998): Homo Sacer: Sovereign power and bare life. Stanford: Stanford University Press.

Ansalone, George (2010): Tracking: Educational differentiation or defective strategy. Educational Research Quarterly 34(2), 3-17.

Ball, Stephen (2012): Foucault, Power and Education. New York: Routledge.

Banks, James A. (2016): Cultural Diversity and Education: Foundations, curriculum, and teaching. 6th ed. New York: Routledge.

Burchell, Graham (1993): Liberal government and technologies of the self. Economy and Society 22(3), 267-282.

Dean, Mitchell (1999): Governmentality: Power and rule in modern society. Thousand Oaks: SAGE Publications.

Didaktisk tidsskrift (2018): Didaktik, pedagogik och metodik. Retrieved 2020-05-29 from http://didaktisktidskrift.se/didaktikpedagogik-och-metodik/

Duffield, Mark (2007): Development, Security and Unending War: Governing the world of peoples. Cambridge: Polity press. 
Eco-Schools - Foundation for Environmental Education (2020): Our program. Retrieved 2020-05-20 from https://www. ecoschools.global/

Englund, Tomas \& Quennerstedt, Ann (2008): Vadå Likvärdighet? Studier i utbildningspolitisk språkanvändning. Göteborg: Daidalos.

Foucault, Michel (1982): The subject and power. In Hubert Dreyfus \& Paul Rabinow, eds.: Michel Foucault: Beyond structuralism and hermeneutics, pp. 208-226. Brighton: Routhledge.

Foucault, Michel (1998): The History of Sexuality Vol.1. Harmondsworth: Penguin.

Foucault, Michel (2008): The Birth of Biopolitics: Lectures at the Collége de France, 1978-1979. Basingstoke: Palgrave.

Gay, Geneva (2002): Preparing for culturally responsive teaching. Journal of Teacher Education 53(1), 106-116.

Giroux, Henry A. (2008): Beyond the biopolitics of disposability: rethinking neoliberalism in the new gilded age. Social Identities 14(5), 587-620.

Gruenewald, David A. \& Smith, Gregory A. (2008): Place-Based Education in the Global Age. New York: Psychology Press.

Grön flagg - Håll Sverige rent (2019): Grön flagg dagen 2019. Retrieved 2020-05-12 from https://skola-kommun.hsr.se/gronflagg/gron-flagg-dagen-2019

Hacking, Ian (1986): "Making up people”. In: Thomas Heller; Morton Sosna \& David E. Wellbery, eds.: Reconstructing Individualism: Autonomy, individuality and the self in the Western thought, pp. 222-236. Stanford: Stanford University Press.

Hansson, Stina; Hellberg, Sofie \& Stern, Maria (2015): Studying the Agency of Being Governed. London: Routledge.

Hartsmar, Nanny \& Jönsson, Karin (2010): Lärandets vem, varför, vad och hur i förskolan och grundskolans tidiga år. In Perspektiv på barndom och barns lärande: En kunskapsöversikt om lärande i förskolan och grundskolans tidigare år. Stockholm: Skolverket.

Hellberg, Sofie \& Knutsson, Beniamin (2018a): Don efter population? Utbildning för hållbar utveckling och det globala biopolitiska GAPet. Pedagogisk Forskning i Sverige 23(3-4), 172191.

Hellberg, Sofie \& Knutsson, Beniamin (2018b): Sustaining the lifechance divide? Education for sustainable development and the global biopolitical regime. Critical Studies in Education 59(1), 93-107. 
Klafki, Wolfgang (1995): Didactic analysis as the core of preparation of instruction. Journal of Curriculum Studies 27(1), 13-30.

Klafki, Wolfgang (1998): Characteristics of critical-constructive didaktik. In: Bjørg B. Gundem \& Stefan Hopmann, eds.: Didaktik and/or Curriculum, pp. 307-330. New York: Peter Lang Publishing.

Knutsson, Beniamin (2013): Swedish environmental and sustainability education research in the era of post-politics? Utbildning \& Demokrati - tidskrift för didaktik och utbildningspolitik 22(2), 105-122.

Knutsson, Beniamin (2019): Segmented prizing: biopolitical differentiation in education for sustainable development. Compare: A Journal of International and Comparative Education https://doi.org/10.1080/03057925.2019.1629276.

Knutsson, Beniamin (2020): Managing the GAP between rich and poor? Biopolitics and (ab)normalized inequality in South African education for sustainable development. Environmental Education Research 26(5), 650-665.

Ladson-Billings, Gloria (1995): But that's just good teaching! The case for culturally relevant pedagogy. Theory Into Practice 34(3), 159-165.

Lemke, Thomas (2011): Biopolitics: An advanced introduction. New York: New York University Press.

Martin, Joanna (2017): Eco-schools Best practice in Uganda, Tanzania and Malawi. Copenhagen: Danish Outdoor Council.

Miller, Peter \& Rose, Nikolas (2008): Governing the Present: Administering economic, social and personal life. Cambridge: Polity.

Månsson, Niclas, \& Nordmark, Jonas (2015): Den allmänna didaktikens gränser - Om möjligheter och begränsningar för en samhällsomvandlande didaktik. Utbildning \& Demokratitidskrift för didaktik och utbildningspolitik 24(3), 1-18.

Nylund, Mattias; Rosvall, Per-Åke, \& Ledman, Kristina (2017): The vocational-academic divide in neoliberal upper secondary curricula: the Swedish case. Journal of Education Policy 32(6), 788-808.

Oakes, Jeannie (1986): Keeping track, part 1: The policy and practice of curriculum inequality. Phi Delta Kappan 61(1), 12-17.

Peters, Michael A. \& Besley, Tina (1997): Why Foucault? New directions in educational research. New York: Peter Lang Publishing. 
Powers, Amy L. (2004): An evaluation of four place-based education programs. The Journal of Environmental Education 35(4), 17-32.

Rytzler, Johannes \& Magnússon, Gunnlaugur (2020): Didaktik som lärarutbildningens innehåll och form: Motstånd, utmaningar och möjligheter. Utbildning \& Demokrati-tidskrift för didaktik och utbildningspolitik 29(1), 49-64.

Skolverket (2020): Didaktik. Retrieved 2020-05-15 from https:// www.skolverket.se/skolutveckling/forskning-och-utvarderingar/ forskning/innehall/sammanstallning-och-spridning-avforskningsresultat

Sleeter, Christine \& Carmona, Judith F. (2017): Un-Standardizing Curriculum: Multicultural teaching in the standards-based classroom. New York: Teachers College Press.

Smith, Gregory A. (2002): Place-based education: Learning to be where we are. Phi Delta Kappan 83(8), 584-594.

Terwel, Jan (2005): Curriculum differentiation: multiple perspectives and developments in education. Journal of Curriculum Studies 37(6), 653-670.

Therborn, Göran (2012): The killing fields of inequality. International Journal of Health Services 42(4), 579-589.

Therborn, Göran (2013): The Killing Fields of Inequality. Cambridge: Polity Press.

Tomlinson, Carol Ann (2000): Reconcilable differences: Standardsbased teaching and differentiation. Educational Leadership 58(1), 6-11.

Ulrika, Johanna (2017-02-27): Dina val styr vad eleverna lär sig. Grundskoleläraren. Retrieved from https://www.lararen.se/ grundskollararen/temafordjupning/dina-val-styr-vad-elevernalar-sig

von Wright, Moira (2000): Vad eller vem? En pedagogisk rekonstruktion av G. H. Meads teori om människors intersubjektivitet. Göteborg: Daidalos.

Wells, Karen (2011): The politics of life: Governing childhood. Global Studies of Childhood 1(1), 15-25.

Venn, Couze (2009): Neoliberal political economy, biopolitics and colonialism: A transcolonial genealogy of inequality. Theory, Culture \& Society 26(6), 206-233.

Wlodkowski, Raymond J. \& Ginsberg, Margery B. (1995): Diversity and motivation: culturally responsive teaching. San Francisco: Jossey-Bass Publishers. 